\title{
A Rare Cause of Nosocomial Infections Associated with Nephrolithiasis; Sphingomonas Paucimobilis
}

\section{Nefrolitiazisin Eşlik Ettiği Nadir Bir Hastane Enfeksiyonu Etkeni; Sphingomonas Paucimobilis}

\author{
Emrah Gün1, Nusret Ayaz¹, Hakan Uzun¹, Mesut Okur¹, İbak Gönen², Cemalettin Güneş¹, \\ Zeyneb Soysal ${ }^{1}$, Kenan Kocabay ${ }^{1}$ \\ 1Düzce Üniversitesi Tıp Fakültesi, Çocuk Sağlığı ve Hastalıkları Anabilim Dalı, Düzce, Türkiye \\ 2Süleyman Demirel Üniversitesi Tıp Fakültesi, Enfeksiyon Hastalıkları Anabilim Dalı, Isparta, Türkiye
}

Received/Geliș Tarihi: 08.04.2013 Accepted/Kabul Tarihi: 28.06.2013

Available Online Date / Çevrimiçi Yayın Tarihi: 31.09.2013

\section{Correspondence} Address

Yazışma Adresi: Emrah Gün, MD

Düzce Üniversitesi Tıp Fakültesi, Çocuk Sağlığı ve Hastalıkları Anabilim Dalı,

Düzce, Türkiye

Phone: +903805421390 E-mail:

emrhgn@hotmail.com

(C) Copyright 2014 by Pediatric Infectious Diseases Society - Available online at www.cocukenfeksiyon.org

(CTelif Hakkı 2014

Çocuk Enfeksiyon Hastalıklar Derneği - Makale metnine www.cocukenfeksiyon.org web sayfasından ulaşılabilir. DOI:10.5152/ced.2013.47

\begin{abstract}
Sphingomonas paucimobilis is a gram negative, nonfermentative, oxidase positive, very slow acting bacillus. In species of Sphingomonas, S. paucimobilis, known as a pathogen, is a rare cause of nosocomial infection. S. paucimobilis is isolated from distilled water, labs, nebulizers, mechanical ventilators and dialysis liquids in hospital. S. paucimobilis is reported to have caused infection among the patients which have chronic disease or a weak immune system, and alcoholics and drug users. In this case we presented a three year old girl patient, diagnosed with nephrolithiasis, who had $S$. paucimobilis her blood culture which was taken because of fever, chills and right costovertebral angle sensitivity on the $11^{\text {th }}$ day. (J Pediatr Inf 2014; 8: 125-7)
\end{abstract}

Key words: Nosocomial infection, Sphingomonas paucimobilis

\section{Giriş}

Sphingomonas paucimobilis toprakta, bitki yüzeylerinde, nehir ve içme sularında yaygın olarak bulunan ve bazen de insanlarda nadiren enfeksiyona neden olan gram negatif, aerobik bir bakteridir $(1,2)$. S. paucimobilis kanlı agarda $S$ şeklinde koloni oluşturan, sarı pigmentli, nonfermentatif, spor oluşturmayan, tek polar flajeli olan, çok yavaş hareketli, oksidaz ve katalaz pozitif, fırsatçı bir hastane enfeksiyonu etkenidir. S. paucimobilis'in; toplum ya da hastane kaynaklı bakteriyemi, peritonit, menenjit, gastroenterit, katater ilişkili sepsis, üriner sistem enfeksiyonları, solunum yolu enfeksiyonları, septik artrit,

\section{Özet}

Sphingomonas paucimobilis, gram negatif, nonfermantatif, oksidaz pozitif, çok yavaş hareketli bir basildir. Sphingomonas türleri içinde patojen olarak bilinen $S$. paucimobilis nadir bir hastane enfeksiyonu etkenidir. S. paucimobilis, hastane ortamında; distile sularda, laboratuvarlarda, nebulizatörlerde, mekanik ventilatörde, diyaliz sıvılarında izole edilmiştir. S. paucimobilis özellikle kronik hastalığı olan, immün sistemi zayıflamış, alkol ve intravenöz ilaç kullanımı öyküsü olan hastalarda enfeksiyona neden olduğu bildirilmiştir. Biz bu olguda nefrolitiazis tanısıyla serviste takip ettiğimiz ve yatışının 11. gününde ateş, titreme ve sağ kostovertebral açı hassasiyeti olması üzerine alınan kan kültüründe $S$. paucimobilis üreyen 3 yaşında kız hastayı sunduk. (J Pediatr Inf 2014; 8: 125-7)

Anahtar kelimeler: Hastane enfeksiyonu, Sphingomonas paucimobilis

osteomiyelit, splenik ve beyin apsesine neden oluğu literatürde bildirilmiştir $(1,3)$. Biz bu olguda; nefrolitiazis tanısıla takip edilen ve amikasin ile mayi tedavisi sonrası şikayetleri gerileyen ancak yatışının 11. gününde ateş, titreme, sağ böğür ağrısı olması üzerine alınan kan kültüründe $S$. paucimobilis saptadığımız 3 yaşında kız hastayı sunduk.

\section{Olgu Sunumu}

Üç yaşındaki kız hasta, sağ böğür ağrısı, kusma ve iştahsızlık şikayetleri ile acil polikliniğimize başvurdu. Hastanın nefrolitiazis nedeniyle hastanede çok sayıda yatışı olduğu ve son yatı- 
şının 1 ay önce olduğu öğrenildi. Soygeçmişinde kardeşinin de nefrolitiazis tanısıyla takip edildiği öğrenildi. Hastanın genel durumu orta, şuur açık ve koopere idi. Fizik muayenede sağ kostovertebral açı hassasiyeti dışında patolojik bulguya rastlanmadı. Hastanın yapılan laboratuvar tetkiklerinde; $\mathrm{Hb}: 11,2 \mathrm{~g} / \mathrm{dL}$, beyaz küre sayımı: 16400/mm ${ }^{3}$, trombosit sayımı: $376000 / \mathrm{mm}^{3}$, C-reaktif protein (CRP): 22,8 mg/dL idi. Böbrek ve karaciğer fonksiyon testleri, koagülasyon tetkikleri normal idi. Tam idrar tahlilinde dansite: 1023 , ph: 5,5, lökosit: ++, eritrosit: +++ ve nitrit: pozitifti. Flow sitometri yöntemi ile bakılan idrar mikroskopisinde 432 eritrosit/High Power field (HPF), 713 lökosit/HPF, 4 bakteri/HPF mevcuttu. Hastanın ayakta düz batın grafisinde sağ böbrek hizasında opasite veren kalkül mevcuttu. Tüm batın ultrasonografide sağ böbrek pelviste $9 \mathrm{~mm}$ ebatlı posteriorda gölgesi bulunan hiperekojen kalkül imajı mevcuttu. Hasta nefrolitiazis tanısıyla servise yatırıldı. İdrar kültürü ve kan kültürü tetkikleri alınan hastaya damar yolu açllarak $15 \mathrm{mg} / \mathrm{kg} / \mathrm{gün}$ 'den amikasin, 1/3 $2000 \mathrm{cc} / \mathrm{m}^{2}$ 'den sıvı tedavisi ve lüzum halinde $10 \mathrm{mg} / \mathrm{kg} / \mathrm{doz}$ 'dan parasetamol tedavisi başlandı. Hastaya idrar sondası takıldı. Hastanın taş etiyolojisine yönelik kalsiyum, parathormon, 25-hidroksi vitamin D, spot idrarda kalsiyum, kreatinin ve kalsiyum/kreatinini normal aralıkta idi. Hastanın immünglobülin $A$ (IgA), immünglobülin $G$ (IgG) ve immünglobülin $M$ (İgM) düzeyi normal aralıkta idi. Kan ve idrar aminoasitleri tetkikinde; idrarda hafif derecede glutamin artışı dışında patolojik bulguya rastlanmadı. Ürolojiye danışılan hastanın operasyona gerek olmadığı ancak hastanede takip edilmesi gerektiği söylendi. İdrar ve kan kültüründe üreme olmayan hastanın yatışının yedinci gününde şikayetleri geriledi. Yedinci gününde alınan tam idrar tetkikinde lökosit, eritrosit ve nitrit negatifti. Beyaz küre sayımı: $8400 / \mathrm{mm}^{3}$, CRP: $0,4 \mathrm{~g} / \mathrm{dL}$ 'ye gerileyen hastanın antibiyotik tedavisi kesildi ancak oral alımı iyi olmadığından mayi tedavisine devam edildi. Yatışının 11. gününde ateş, titreme şikayetleri olan hastanın yapılan fizik muayenesinde sağ kostovertebral açı hassasiyeti dışında patolojik bulguya rastlanmadı. Hastanın laboratuvar tetkiklerinde beyaz küre sayımı: 10900/mm³ $\mathrm{Hb}: 11,4 \mathrm{~g} / \mathrm{dL}$, CRP: $2,3 \mathrm{mg} / \mathrm{dL}$ idi. Böbrek ve karaciğer fonksiyon testleri, koagülasyon tetkikleri normal idi. Tam idrar tetkikinde lökosit: +, eritrosit ve nitrit negatifti. İdrar ve kan kültürü gönderildi. Hastaya $100 \mathrm{mg} / \mathrm{kg} / \mathrm{gün} d e n$ seftriakson tedavisi verildi. İdrar kültüründe üreme olmadı. Hastadan yatışının 11. gününde alınan kan kültüründe gram negatif üreme saptandı. Bakteri VITEK 2 otomotize sistemi (bioMerieux Inc, Mercy L'etoli, Fransa) kulanılarak S. paucimobilis olarak isimlendirildi. Bakterinin seftriakson, gentamisin, amikasin, piperasilin, siprofloksasin, seftazidime duyarlı; kolistine dirençli olduğu bildirildi. Hastanın seftriakson tedavisine 7 gün devam edildi. Hastanın şikayetleri gerilemişti ve oral alımı iyiydi. Beyaz küre sayımı: $8000 / \mathrm{mm}^{3}$, CRP: 0,10 g/ dL'ye gerileyen, genel durumu iyi ve vital bulguları stabil olan hastanın antibiyotik tedavisi parenteral olarak 10 güne tamamlanacak şekilde taburcu edildi. Hasta çocuk nefrolojisi olan bir merkeze yönlendirildi.

\section{Tartışma}

S. paucimobilis ilk olarak 1977 yılında insanlarda bir ajan olarak keşfedildi ve Pseudomonas paucimobilis olarak adlandırıldı (3). 1979 yılında bacak ülseri, menenjit, septisemi nedeni olarak bildirildi ve 1990 yılında adı S. paucimobilis olarak değiştirildi $(1,3)$. Sphingomonas türleri içinde Sphingomonas mucosissima ve Sphingomonas adhesiva gibi klinik önemi olmayan mikroorganizmalar mevcuttur ancak patojen etkisi en iyi bilinen S. paucimobilis'tir (4). S. paucimobilis'in, Pseudomonas'a göre virulansı daha düşüktür ve nadiren hastane enfeksiyonuna neden olur (5). S. paucimobilis' in hücre duvarında lipopolisakkaritleri içermemesi ve dolayısıyla endotoksin üretiminin olmaması bundan sorumlu tutulmaktadır (6).

Hastane ortamında su sistemlerinde, distile sularda, lavabolarda, diyaliz sıvısında, respiratörlerde, nebülizatör gibi çeşitli ortamlarda izole edilen S. paucimobilis toplum ve hastane kaynaklı enfeksiyonlara sebep olabilmektedir (1). Kronik böbrek yetmezliği, kronik akciğer hastalığı gibi altta yatan kronik hastalığı olanlarda ve alkol, intravenöz ilaç kullanımı, immünsüpresif ilaç kullananlarda S. paucimobilis'e bağlı ciddi enfeksiyonların gelişebileceği bildirilmiştir (7).

Etken olarak S. paucimobilis saptanan 16 hastayı içeren bir çalışmada, hastaların ortalama yaşı 48,5 yıl olup hastaların \%57'sinde malignite, \%40'ında immünsupresif kullanım öyküsü ve \%11,9'unda diyabetes mellitus gibi altta yatan bir hastalığın mevcut olduğu raporlanmıştır. Bu çalışmada S. paucimobilis enfeksiyonlarının \%69'unun hastane kökenli bakteriyemi ile ilişkili olduğu tespit edilmiştir. Bu çalışmada S. paucimobilis' a bağlı ölüm bildirilmemiştir. Bu çalışmada en etkili antibiyotiklerin florokinolon, karbapenem, beta-laktam ve betalaktamaz inhibitör kombinasyonları olduğu bildirilmiştir (8). Bizim hastamızda immünglobulin düzeyi normal aralıktaydı ve belirgin bir immün yetmezliği yoktu.

S. paucimobilis'in, akut miyeloid lösemisi tanısı ile takip edilen bir hastada kök hücre transplantasyonu öncesinde septik şoka, periton diyalizi yapılan bir hastada peritonite ve başka bir olguda endoftalmite neden olduğu bildirilmiştir $(9,10)$. Kardiyak cerrahi öyküsü olan Down sendrom'lu bir hastada pnömoniye ve ventriküloperitoneal şantlı bir hastada bronkopnömoniye neden olduğu bildirilmiştir $(1,3)$. Ülkemizde yapılan bir çalışmada submandibuler sialolitiazis zemininde S. paucimobilis' 
in üretildiği bildirilmiştir (11). Bizim olgumuzda nefrolitiazis mevcuttu ve literatürde nefrolitiazis ile ilişkili S. paucimobilis enfeksiyonuna rastlamadık. S. Paucimobilis'in sialolitiazis zemininde ve olgumuzda olduğu gibi nefrolitiazisli bir hastada üretilmesi taş zemininde görülme riskinin artmış olabileceğini göstermektedir (11).

\section{Sonuç}

Doğada yaygın olarak bulunan ve bazen de hastane ortamında izole edilen S. paucimobilis, nadir bir hastane enfeksiyonu etkenidir (1). Özellikle kronik hastalık öyküsü olan ve immün sistemi zayıf hastalarda ciddi enfeksiyonlara neden olabilir (9). Hastalar antibiyogramdaki duyarlı antibiyotiklerle tedavi edilmelidir.

Informed Consent: Written informed consent was obtained from patients who participated in this study.

Peer-review: Externally peer-reviewed.

Author Contributions: Concept - E.G., M.O.; Design E.G., N.A.; Supervision - H.U., I.G.; Funding - C.G., Z.S.; Materials - E.G., N.A.; Data Collection and/or Processing - E.G., N.A.; Analysis and/or Interpretation - E.G., N.A.; Literature Review - E.G., N.A.; Writing - E.G., N.A.; Critical Review - M.O., H.U., K.K.; Other - E.G.,N.A.

Conflict of Interest: No conflict of interest was declared by the authors.

Financial Disclosure: The authors declared that this study has received no financial support.

Hasta Onamı: Yazılı hasta onamı bu çalışmaya katılan hastalardan alınmıştır.

Hakem değerlendirmesi: Dış bağımsız.

Yazar Katkıları: Fikir - E.G., M.O.; Tasarım - E.G., N.A.; Denetleme - H.U., I.G.; Kaynaklar - C.G., Z.S.; Malzemeler - E.G., N.A.; Veri toplanması ve/veya işlemesi - E.G., N.A.; Analiz ve/veya yorum - E.G., N.A.; Literatür taraması - E.G., N.A.; Yazıyı yazan - E.G., N.A.; Eleştirel İnceleme - M.O., H.U., K.K.; Diğer - E.G., N.A.

Çıkar Çatışması: Yazarlar herhangi bir çıkar çatışması bildirmemişlerdir.

Finansal Destek: Yazarlar bu çalışma için finansal destek almadıklarını beyan etmişlerdir.

\section{Kaynaklar}

1. Bulut C, Yetkin MA, Koruk ST, et al. Sphingomonas paucimobilis: A rare nosocomial bacteriemia agent. Mikrobiyol Bul 2008; 42: 685-8.

2. Mutlu M, Bayramoglu G, Yilmaz G, et al. Outbreak of Sphingomonas paucimobilis septicemia in a neonatal intensive care unit. Indian Pediatr 2011; 48: 723-5. [CrossRef]

3. Özdemir M, Pekcan S, Demircili ME et al. A rare cause of bacteremia in a pediatric patient with Down syndrome: Sphingomonas paucimobilis. Int J Med Sci 2011; 8: 537-9. [CrossRef]

4. Al-Anazi KA, Abu Jafar S, Al-Jasser AM et al. Septic shock caused by Sphingomonas paucimobilis bacteremia in a patient with hematopoietic stem cell transplantation. Transpl Infect Dis 2008; 10: 142-4. [CrossRef]

5. Seo SW, Chung IY, Kim E, Park JM. A Case of Postoperative Sphingomonas paucimobilis endophthalmitis after cataract ex-traction. Korean Journal of Ophthalmology 2008; 22: 63-5. [CrossRef]

6. Hsueh PR, Teng LJ, Yang PC, et al. Nosocomial infections caused by Sphingomonas paucimobilis: clinical features and microbiological characteristic. Clin Infect Dis 1998; 26: 676-81. [CrossRef]

7. Perola O, Nousiainen $\mathrm{T}$, Suomalainen $\mathrm{S}$, et al. Recurrent Sphingomonas paucimobilis-bacteraemia associated with a multi-bacterial water-borne epidemic among neutropenic patients. J Hosp Infect 2002; 50: 196-201. [CrossRef]

8. Lin JN, Lai $\mathrm{CH}$, Chen $\mathrm{YH}$ et al. Sphingomonas paucimobilis bacteremia in humans: 16 case reports and a literature review. J Microbiol Immunol Infect 2010; 43: 35-42. [CrossRef]

9. Kilic A, Senses Z, Kurekci AE, et al. Nosocomial outbreak of Sphingomonas paucimobilis bacteremia in a hemato/oncology unit. Jpn J Infect Dis 2007; 60: 394-6.

10. Dervisoglu E, Meric M, Kalender B, Sengul E. Sphingomonas paucimobilis Peritonitis: a Case Report and Literature Review. Peritoneal Dialysis International 2008; 28: 547-50.

11. Karabıçak $C$, Karabıçak $H$, Ağalar $C$, Kazkayası $M$. Sphingomonas paucimobilis infection with underlying submandibular sialolithiasis. Kulak Burun Bogaz Ihtis Derg 2011; 21: 49-51. 